Article

\title{
Coupling of Biochar with Nitrogen Supplements Improve Soil Fertility, Nitrogen Utilization Efficiency and Rapeseed Growth
}

\author{
Zaid Khan ${ }^{1}$, Kangkang Zhang ${ }^{1}$, Mohammad Nauman Khan ${ }^{1}$, Shah Fahad ${ }^{1,2}$, Zhenghua Xu ${ }^{1}$ \\ and Liyong $\mathrm{Hu}^{1}$,* \\ 1 MOA Key Laboratory of Crop Ecophysiology and Farming System in the Middle Reaches of \\ the Yangtze River, College of Plant Science and Technology, Huazhong Agricultural University, \\ Wuhan 430070, China; zaidkhan@webmail.hzau.edu.cn (Z.K.); zhangkk@webmail.hzau.edu.cn (K.Z.); \\ nauman@webmail.hzau.edu.cn (M.N.K.); shah_fahad80@yahoo.com (S.F.); xzh@mail.hzau.edu.cn (Z.X.) \\ 2 Department of Agronomy, The University of Haripur, Haripur 22620, Pakistan \\ * Correspondence: liyonghu@mail.hzau.edu.cn; Tel.: +86-189-7119-8168
}

Received: 15 September 2020; Accepted: 20 October 2020; Published: 28 October 2020

\begin{abstract}
Compensating nitrogen input and increasing nitrogen utilization efficiency (NUtE) are necessary for sustainable crop production. Research studies on the co-application of biochar and nitrogen to promote rapeseed growth, soil fertility, and improve nutrient utilization efficiency are found to be limited. This study aims to examine the integral effects of biochar and nitrogen over soil fertility, rapeseed growth and nitrogen utilization efficiency. The experiment was conducted in a completely randomized design to assess various morphological, physiological and biochemical traits of rapeseed and soil chemical properties under the application of four nitrogen levels $\left(0,75,225\right.$, and $450 \mathrm{~kg} \mathrm{ha}^{-1}$ equivalent to $0,133,400$ and $800 \mathrm{mg}$ nitrogen pot $\left.{ }^{-1}\right)$ and four biochar levels $\left(0,5,10\right.$, and $15 \mathrm{MT} \mathrm{ha}^{-1}$ equivalent to $0,10,20$ and $30 \mathrm{~g}$ biochar pot $^{-1}$ soil by weight basis). The results of this study showed that the integral application of biochar at $30 \mathrm{~g} \mathrm{pot}^{-1}$ and nitrogen at $800 \mathrm{mg} \mathrm{pot}^{-1}$ at 45 days after sowing (DAS) and 60 days after sowing (DAS) compensated the amount of nitrogen and increased soil organic carbon (SOC 69\%), total nitrogen accumulation (TNA) $(93 \%$ and $62 \%$ ), leaf biomass (60\% and $33 \%)$, stem biomass ( $20 \%$ and $22 \%$ ) and photosynthesis $(20 \%$ and $17 \%)$ at 45 DAS and 60 DAS, respectively as compared to a single application of nitrogen. However, under the conditions of no nitrogen or $75 \mathrm{~kg} \mathrm{ha}^{-1}$ nitrogen application, the application of biochar to promote the growth of rapeseed plants is limited due to the less nitrogen supply. In contrast, the application of nitrogen at $800 \mathrm{mg} \mathrm{pot}^{-1}$ and biochar at 10 or $20 \mathrm{~g} \mathrm{pot}^{-1}$ showed that the growth of early seedlings was adversely affected due to high nitrogen concentration in soil. The findings of the present study imply that within the appropriate nitrogen application range, the interaction of biochar and nitrogen might have an economical approach towards better utilization of nitrogen and sustainable crop production.
\end{abstract}

Keywords: soil organic matter; photosynthesis; total nitrogen accumulation; sustainable crop production

\section{Introduction}

An increase up to $34 \%$ in world's population by 2050 is predicted to increase demand of food production [1], and various developing countries with less nitrogen use efficiency and declined soil fertility raising many problems for food security and less crop production [2,3]. Rapeseed is the first oilseed and fourth major crop after rice, maize, and wheat in China. China has become one of the top rapeseed producers around the world since 1980, except for 2011 [3]. Yangtze River Basin is the largest rapeseed production region in China, with about $90 \%$ of the total national rapeseed production [4]. 
The yield of rapeseed is closely related to the application of fertilizer, especially the supply of available nitrogen. However, compared with the world's major rapeseed producing countries, China's rapeseed nitrogen fertilizer consumption is significantly higher than Australia, Germany, and other countries, in contrast, the agronomic efficiency of nitrogen fertilizer is only about $1.63-8.08 \mathrm{~kg} \mathrm{~kg}^{-1} \mathrm{~N}$, that is much lower than Australia and Germany's $8.32-8.80 \mathrm{~kg} \mathrm{~kg}^{-1} \mathrm{~N}$, respectively [5]. High-level application of nitrogen fertilizer will not only reduce the nitrogen fertilizer use efficiency due to ammonia volatilization and nitrate $\left(\mathrm{NO}^{-3}-\mathrm{N}\right)$ leaching [6] but also cause soil acidification [7] and environmental pollution problems [8]. At the same time, the yield, quality, and efficiency of plants will be reduced due to excessive vegetative growth, reduced stress resistance, and increased lodging [9]. Thus, increasing the nitrogen utilization efficiency (NUtE) of rapeseed through the integrated use of biochar and nitrogen is of significant importance to mitigate the problems of fertilizer consumption, environmental contamination, and economic cost of the production of rapeseed, while maintaining the crop yield and quality.

Biochar which is prepared through pyrolysis of plant biomass is a carbon-rich organic compound, and its application has been described as a low-cost method, which enhances soil physio-chemical properties, crop yield and decreases inorganic fertilizer application which will increase availability and utilization of the nutrients, farm productivity and income [10]. Biochar contains organic matter, ash, and various nutrients [11], which enhance soil organic carbon, soil $\mathrm{pH}$, electrical conductivity and cation-exchange capacity [12], which will further minimize the volatilization of ammonium and enhance the immobilization and availability of nitrogen and other nutrients for field crops [13]. The presence of oxygen-containing functional groups on the surface of biochar helps to adhere more water particles to improves water holding capacity (WHC) and water use efficiency (WUE) of soil, hence, increasing water and nutrients retention and thus enhancing the soil fertility and crop productivity [14]. The addition of biochar has a strong effect on root growth and root morphology due to high surface area and high porosity of biochar [15]. The presence of hydroxyl and carboxyl groups in biochar [16] established an adhesion and cohesion forces that are resulting in nutrients conservation to enhance slowly and gradual supply of nutrients through roots for better growth of plants [17].

Many research studies on biochar have been focused on studying the biochar effects on total biomass production. However, little observations are available about the role of biochar in plant physiology, improving NUtE, and soil fertility, respectively. Therefore, it is necessary to systematically explore the effects of biochar over morphological and physiological parameters of crop and examined the soil chemical properties under different nitrogen levels to observe better results and the role of biochar in crop production. Integrated application of biochar and nitrogen could be one of the primary game-changer in nitrogen transformation, soil fertility, and long-term sustainable production of rapeseed. Therefore, we made a complete focus in our research study to explore the positive effects of the integrated application of biochar and nitrogen amendments on NUtE, soil fertility, and morphological and physiological status of rapeseed growth.

\section{Materials and Methods}

\subsection{Experimental Design and Materials}

The experiment was conducted in pots in the open experimental area to evaluate the combined effect of biochar and nitrogen over rapeseed growth, nutrients uptake, and soil fertility. Huayuoza 9 (HZ 9, Hybrid) widely cultivated rapeseed cultivar originated from Huazhong Agricultural University with $\geq 90 \%$ germination rate was used as planting material. Pots used in the experiment were PVC pipes ( $40 \mathrm{~cm}$ length, $10 \mathrm{~cm}$ width) equipped with pored bottom and filled with $4 \mathrm{~kg}$ sun-dried and sieved $(2 \mathrm{~mm})$ mixed soil of clay and sand (2:1). Biochar was derived by pyrolysis of rice straw at a high temperature of $600{ }^{\circ} \mathrm{C}$ produced by Hubei Jinzhi Eco-Energy Co., Ltd., Xiaogan City, Hubei Province, China. Biochar with a $\mathrm{pH}$ of 9.42 containing $0.74 \%$ nitrogen, $47.14 \%$ carbon, $1.62 \%$ hydrogen, 
$11.85 \%$ oxygen, $0.32 \%$ phosphorus, $18.90 \%$ potassium and $19.43 \%$ ash were used in the experiment (Table 1).

Table 1. Chemical properties of biochar and soil before the experiment.

\begin{tabular}{llll}
\hline Properties of Biochar & Values & Properties of Soil & Values \\
\hline $\mathrm{pH}$ & 9.42 & $\mathrm{pH}$ & 5.64 \\
Nitrogen & $0.74 \%$ & Electric conductivity & 1.2 \\
Carbon & $47.14 \%$ & Total nitrogen & $0.7 \mathrm{~g} \mathrm{k} \mathrm{g}^{-1}$ \\
Hydrogen & $1.62 \%$ & Available phosphorus & $11.27 \mathrm{mg} \mathrm{kg}^{-1}$ \\
Oxygen & $11.85 \%$ & Available potassium & $63.43 \mathrm{mg} \mathrm{kg}^{-1}$ \\
Potassium & $18.9 \%$ & Soil organic carbon & $7.42 \mathrm{~g} \mathrm{~kg}^{-1}$ \\
Phosphorus & $0.32 \%$ & Soil organic matter & $12.79 \mathrm{~g} \mathrm{~kg}^{-1}$ \\
Ash & $19.43 \%$ & & \\
\hline
\end{tabular}

The experiment was conducted in a completely randomized design consisting of four nitrogen levels $\left(0,75,225\right.$, and $450 \mathrm{~kg} \mathrm{ha}^{-1}$ equivalent to $0,133,400$ and $800 \mathrm{mg}$ nitrogen pot $\left.{ }^{-1}\right)$ and four biochar

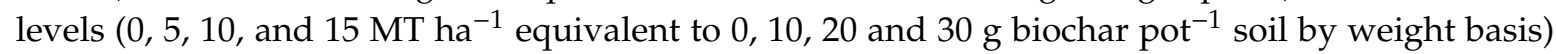
having sixteen treatments and each treatment was repeated twelve times. The sixteen different treatments were $(\mathrm{B} 0+\mathrm{N} 0, \mathrm{~B} 5+\mathrm{N} 0, \mathrm{~B} 10+\mathrm{N} 0, \mathrm{~B} 15+\mathrm{N} 0, \mathrm{~B} 0+\mathrm{N} 75, \mathrm{~B} 5+\mathrm{N} 75, \mathrm{~B} 10+\mathrm{N} 75, \mathrm{~B} 15+\mathrm{N} 75, \mathrm{~B} 0+\mathrm{N} 225$, $\mathrm{B} 5+\mathrm{N} 225, \mathrm{~B} 10+\mathrm{N} 225, \mathrm{~B} 15+\mathrm{N} 225, \mathrm{~B} 0+\mathrm{N} 450, \mathrm{~B} 5+\mathrm{N} 450, \mathrm{~B} 10+\mathrm{N} 450$, and $\mathrm{B} 15+\mathrm{N} 450)$. Biochar and nitrogen were mixed at $20 \mathrm{~cm}$ depth in the soil at the desired rates before the sowing of seeds in pots. Phosphorus and potassium were applied as $\mathrm{P}_{2} \mathrm{O}_{5}\left(550 \mathrm{mg} \mathrm{pot}^{-1}\right)$ and $\mathrm{K}_{2} \mathrm{O}\left(337 \mathrm{mg} \mathrm{pot}^{-1}\right)$ before sowing as basal fertilizer. Four seeds of rapeseed were sown per pot and then thinned to one plant after the establishment of a seedling. All the agronomic practices such as irrigation, weeding, insecticides, and pesticides were provided to all the pots similarly throughout the experiment duration.

\subsection{Samples Measurement and Analysis}

Rapeseed seeds were sown at 13 March 2019 and seedlings were sampled at three different intervals: 30 DAS, 45 DAS, and 60 DAS for measuring various morphological, physiological and biochemical aspects of rapeseed. Three plants were harvested each time to represent a replicate. Stem diameter was measured by using a digital Vernier calliper. The chlorophyll content of leaf was measured by chlorophyll meter SPAD-502 Plus each time in the same leaf used for photosynthesis measurements at 30 DAS, 45 DAS, and 60 DAS. Samples were separated into leaves, stem, and roots and oven-dried at $80{ }^{\circ} \mathrm{C}$ to measure the dry biomass.

\subsection{Determination of Physiological Aspects}

The physiological processes, photosynthetic rate $(\mathrm{A})$, transpiration rate $(\mathrm{E})$, stomatal conductance (gs), and intercellular $\mathrm{CO}_{2}$ rate (Ci) were measured at 30 DAS, 45 DAS, and 60 DAS. Each time, fully expanded the fourth leaf from bottom to top was selected from each pot by using a portable photosynthesis system (Li-6400, Li-COR Inc., Lincoln, NE, USA). All the measurements were carried out from 10:00 am to 03:00 pm in full sunshine under these conditions: leaf temperature $23^{\circ} \mathrm{C}$, $\mathrm{CO}_{2}-400 \mu \mathrm{mol} \mathrm{mol}^{-1}$, light intensity $1000 \mu \mathrm{mol} \mathrm{m}^{-2} \mathrm{~s}^{-1}$, and air humidity $70 \%$.

\subsection{Soil Chemical Properties Analysis}

Initially, three samples of soil were taken before the experiment to measure the basic chemical properties of test soil. Similarly, three replicated samples of soil from each treatment up to $20 \mathrm{~cm}$ depth were taken after harvesting the seedlings at $60 \mathrm{DAS}$ and oven-dried to measure the chemical properties of soil. Digital pH meter (B-212, HORIBA, Ltd., Kyoto City, Japan) and EC meter (B-173, HORIBA, Ltd., Kyoto City, Japan) were used to measure soil $\mathrm{pH}$ and electric conductivity by mixing $10 \mathrm{~g}$ of dry soil sample with distilled water at the ratio of 1:2 and shaken at 180 rounds/min for twenty minutes to 
mix properly. $1 \mathrm{~g}$ of soil was weighed and digested using perchloric and sulphuric acid, and then TN was measured through the micro-Kjeldahl procedure [18]. Available K (AK) was measured using the ammonium acetate solution. Olsen's method with a $0.5 \mathrm{~m} \mathrm{NaHCO}_{3}$ solution of $8.5 \mathrm{pH}$ was used to extract available $\mathrm{P}(\mathrm{AP})$ [19]. $\mathrm{NH}_{4}{ }^{+}-\mathrm{N}$ and $\mathrm{NO}_{3}{ }^{-}-\mathrm{N}$ were measured by indophenol methods [20] and the Catalado method [21], respectively. Weighed $0.3 \mathrm{~g}$ soil to measure soil organic carbon according to the standard method mentioned in [22].

\subsection{Determination of Shoot and Root Nitrogen Content, NUtE, and TNA}

Shoot and root nitrogen contents were measured through the micro-Kjeldahl procedure [18]. Nitrogen utilization efficiency and total nitrogen accumulation were measured using the following equations [23,24].

$$
\begin{gathered}
\text { NUtE }=\text { Plant dry weight/Nitrogen concentration }\left(\mathrm{g}^{2} \mathrm{TDW} \mathrm{mg}^{-1} \mathrm{~N}\right) \\
\text { TNA }=\mathrm{N} \text { concentration } \times \text { total plant dry weight }(\mathrm{mg} \mathrm{N})
\end{gathered}
$$

\subsection{Statistical Analysis}

Two-way ANOVA and significant differences among various treatments were tested by using statistix 8.1 software (Analytical Software, Tallahassee, FL, USA). Differences in means of different treatments were compared by using the least significant difference (LSD). The Figures were drawn using GraphPad Prism 8.0 software (GraphPad, San Diego, CA, USA).

\section{Results}

\subsection{Changes in Physiological Aspects of Rapeseed Seedlings}

The current study was performed to measure the adverse effects of low and high nitrogen on rapeseed growth and physiology through integral application of biochar as evident in (Figure 1). Photosynthetic (A), transpiration (E), stomatal conductance (gs), and intercellular $\mathrm{CO}_{2}$ rates were measured at 30 DAS, 45 DAS, and 60 DAS to observe the changes in physiological processes of rapeseed seedlings due to different treatments of biochar and nitrogen. Application of B15+N450 showed significant increases in photosynthesis rate (A) up to $20 \%$ and $17 \%$, transpiration rate (E) $5 \%$ and $8 \%$, stomatal conductance (gs) $29 \%$ and $11 \%$ and intercellular $\mathrm{CO}_{2} 6 \%$ and $5 \%$ at $45 \mathrm{DAS}$ and 60 DAS of intervals respectively as compared to the sole application of N450 (Figures 2 and 3). However, the application of biochar at 30 DAS of interval did not show a significant response over the physiological traits of rapeseed seedlings. The interaction between nitrogen and biochar was not significant for photosynthetic processes. SPAD values also showed a significant response to an integral application of biochar and nitrogen and increase up to 3\% at 45 DAS, and $10 \%$ at 60 DAS of interval for B15+N450 compared to B0+N450 (Table 2). These results suggested that biochar application can increase chlorophyll contents and photosynthetic rates and, consequently, dry matter production and rapeseed growth. 


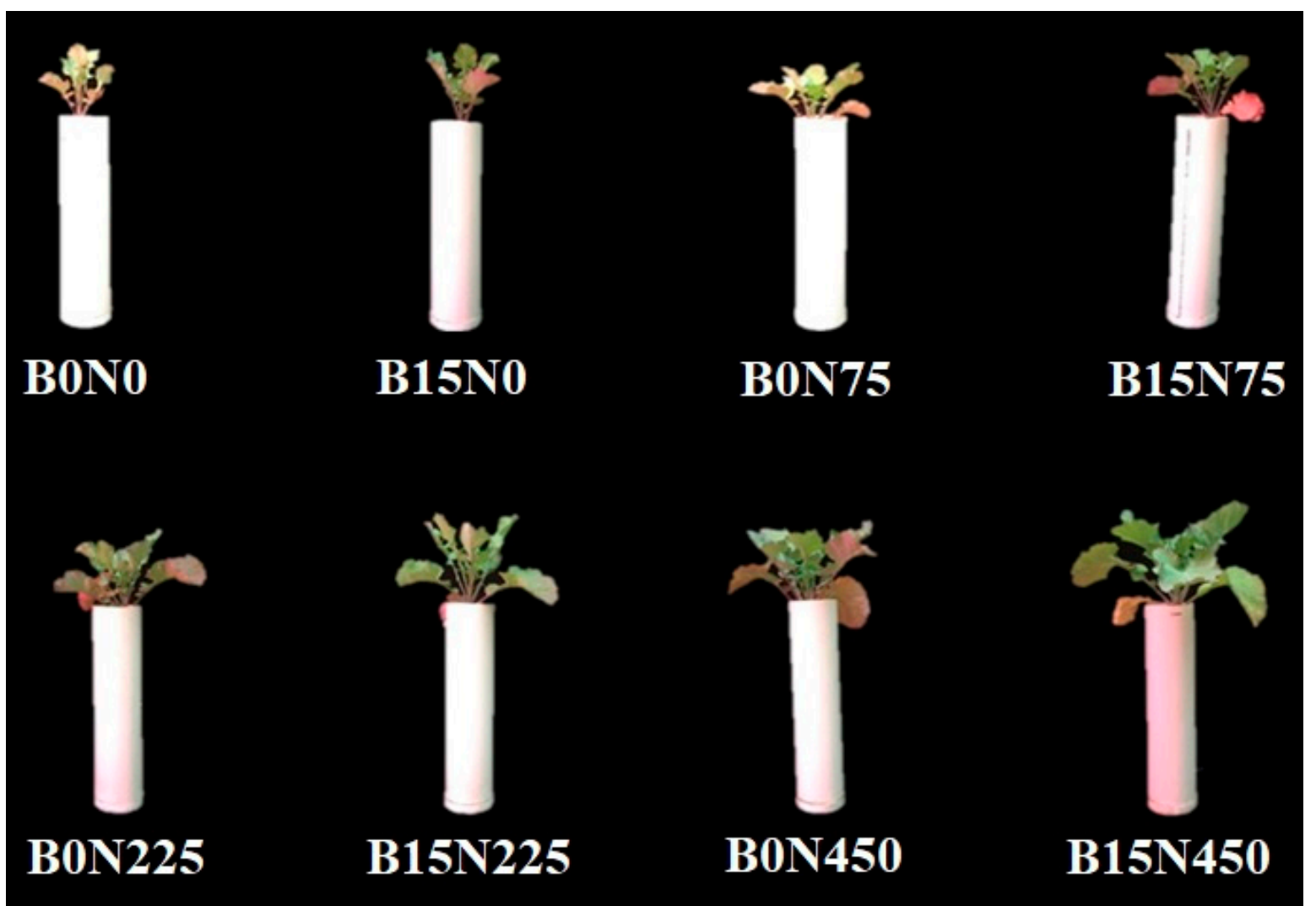

Figure 1. Integral effect of different nitrogen levels (N0, N75, N225 and N450) with high or without biochar (B0 and B15) on rapeseed phenotypes.
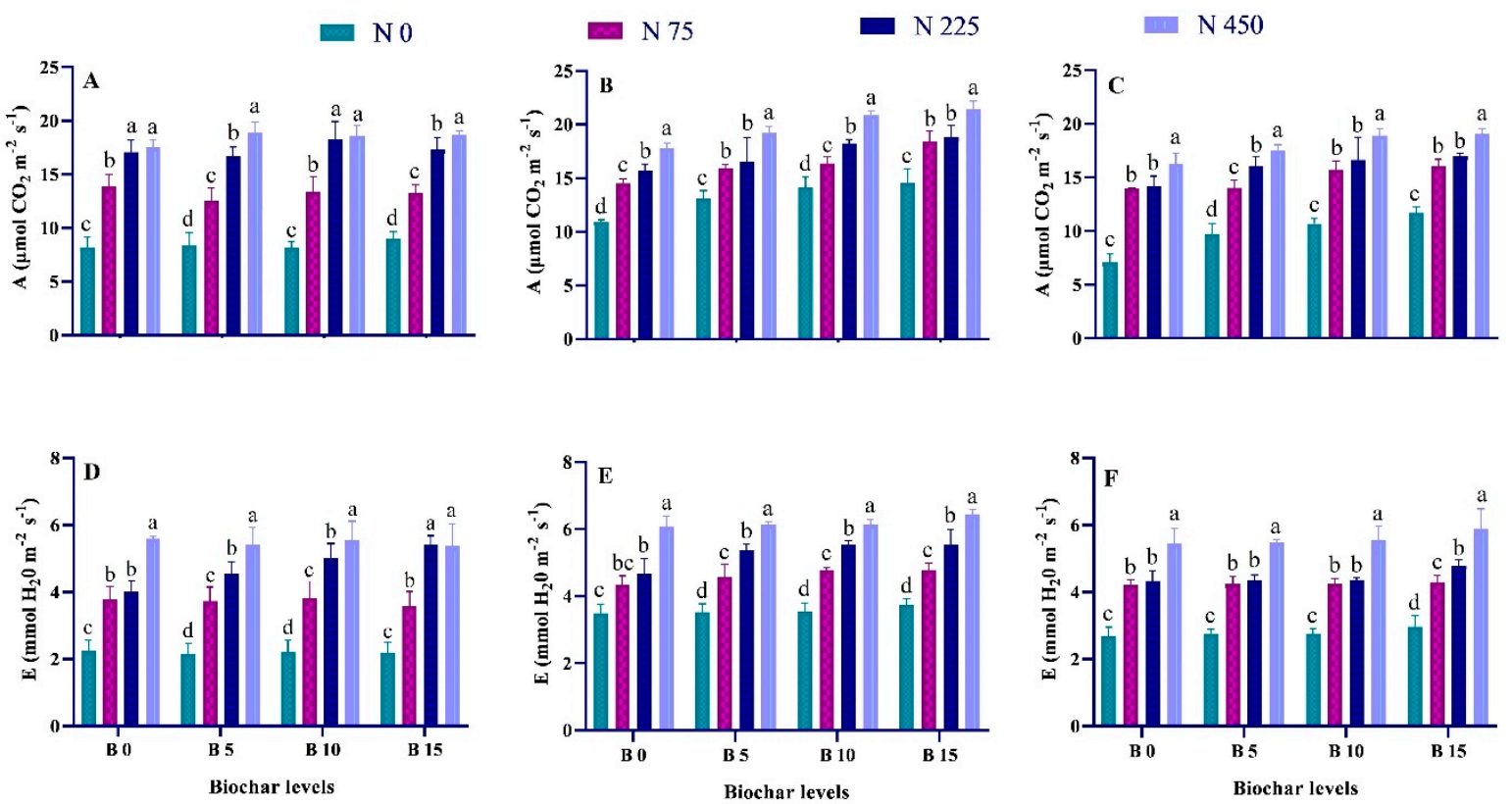

Figure 2. Effects of integrated application of biochar and nitrogen on rapeseed photosynthesis A (A) 30 DAS, (B) 45 DAS and (C) 60 DAS and transpiration E (D) 30 DAS, (E) 45 DAS and (F) 60 DAS under integrated application of biochar and nitrogen. 30 DAS: 30 days after sowing, 45 DAS: 45 days

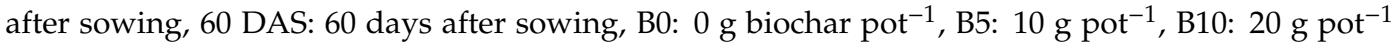
and B15: $30 \mathrm{~g} \mathrm{pot}^{-1}$, N0: $0 \mathrm{mg}$ nitrogen pot $^{-1}$, N75: $133 \mathrm{mg} \mathrm{pot}^{-1}, \mathrm{~N} 225: 400 \mathrm{mg} \mathrm{pot}^{-1}$ and N450: $800 \mathrm{mg} \mathrm{pot}^{-1}$, error bars represents standard error of three replicates. Differences in letters indicate significant differences according to the LSD test $(p<0.05)$. 

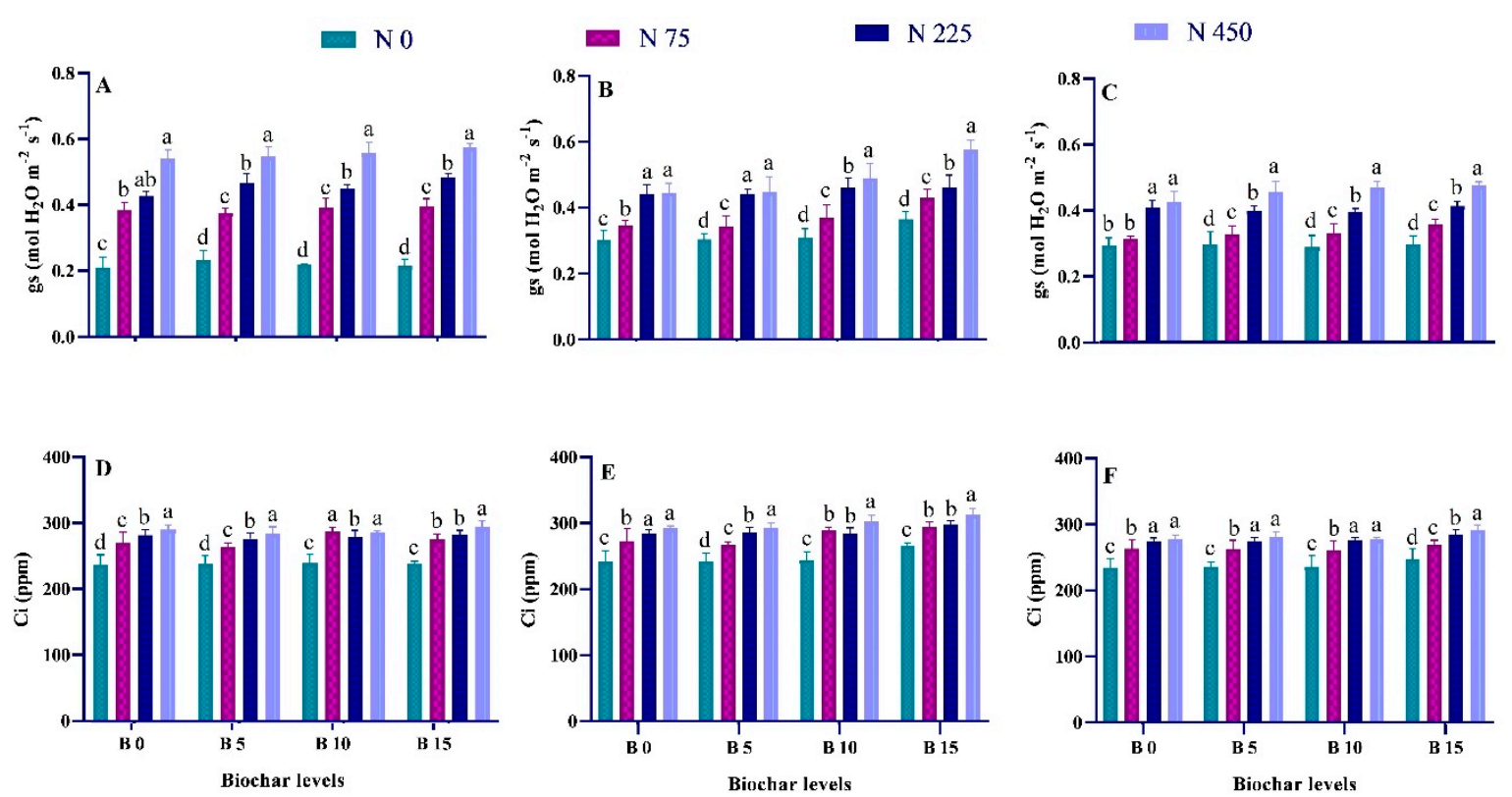

Figure 3. Changes in rapeseed stomatal conductance gs (A) 30 DAS, (B) 45 DAS, and (C) 60 DAS and Ci (D) 30 DAS, (E) 45 DAS and (F) 60 DAS under integrated application of biochar and nitrogen. 30 DAS: 30 days after sowing, 45 DAS: 45 days after sowing, 60 DAS: 60 days after sowing, B0: $0 \mathrm{~g}$ biochar pot $^{-1}$, B5: $10 \mathrm{~g} \mathrm{pot}^{-1}, \mathrm{B10}: 20 \mathrm{~g} \mathrm{pot}^{-1}$ and B15: $30 \mathrm{~g} \mathrm{pot}^{-1}$, N0: $0 \mathrm{mg}$ nitrogen $\operatorname{pot}^{-1}, \mathrm{N75}: 133 \mathrm{mg} \mathrm{pot}^{-1}$, N225: $400 \mathrm{mg} \mathrm{pot}^{-1}$ and N450: $800 \mathrm{mg} \mathrm{pot}^{-1}$, error bars represents standard error of three replicates. Differences in letters indicate significant differences according to the LSD test $(p<0.05)$.

\subsection{Integrated Application of Biochar and Nitrogen Improved Morphology and Biomass of Rapeseed Seedling}

Different biochar and nitrogen fertilizer rates were applied to measure the changes in various morphological contents of rapeseed seedlings at 30 DAS, 45 DAS, and 60 DAS of intervals. Biochar application at 30 DAS of interval increased the morphological traits; however, the effect was not significant as compared to 45 DAS or 60 DAS of intervals. The leaf area showed significant differences in treating biochar with nitrogen and increased leaf area by $29 \%$ at 45 DAS and $7 \%$ at 60 DAS for B15+N450 treatment compared to the application of nitrogen fertilizers without biochar $(\mathrm{B} 0+\mathrm{N} 450)$ (Table 2). Plants treated with biochar application along with nitrogen (B15+N450) also increased stem diameter $15 \%$ at 45 DAS and $4 \%$ at 60 DAS compared to the sole application of nitrogen N450 (Table 2). Significant changes were observed in biomass of rapeseed seedlings, but only root dry weight was increased with biochar application at 30 DAS of the interval, which shows that biochar has a more prominent effect directly on root growth. Leaves dry weight increased by $60 \%$ at 45 DAS and $33 \%$ at 60 DAS in B15+N450 treatment compared to B0+N450 (Table 3). Similarly, stem dry weight showed a significant response to biochar application along with nitrogen fertilizer and enhanced stem dry weight by $20 \%$ at 45 DAS and $22 \%$ at 60 DAS in B15+N450 treatment compared to B0+N450 (Table 3). Root dry weight increases along with an integrated application of biochar and nitrogen at $30 \mathrm{DAS}, 45 \mathrm{DAS}$, and 60 DAS. Increases in root dry weight recorded were $4 \%$ at $30 \mathrm{DAS}, 17 \%$ at $45 \mathrm{DAS}$, and $32 \%$ at 60 DAS for B15+N450 compared to B0+N450 (Table 3). Moreover, the interaction between biochar and nitrogen was also significant at 45 DAS and 60 DAS intervals for dry leaf weight and only at 60 DAS for stem and root dry weight. Increments in leaf morphology and biomass of rapeseed under integral application of biochar and nitrogen showed that biochar enhanced the utilization of nitrogen and improved rapeseed growth. 
Table 2. Effects of integrated application of biochar and nitrogen on leaf area, stem diameter and SPAD values of rapeseed.

\begin{tabular}{|c|c|c|c|c|c|c|c|c|c|c|}
\hline \multirow{2}{*}{ Nitrogen Levels } & \multirow{2}{*}{ Biochar Application } & \multicolumn{3}{|c|}{ Leaf Area $\left(\mathrm{cm}^{2}\right)$} & \multicolumn{3}{|c|}{ Stem Diameter $(\mathrm{mm})$} & \multicolumn{3}{|c|}{ SPAD (Chlorophyll Number) } \\
\hline & & 30 DAS & 45 DAS & 60 DAS & 30 DAS & 45 DAS & 60 DAS & 30 DAS & 45 DAS & 60 DAS \\
\hline \multirow[t]{4}{*}{ No } & B0 & $91.17 \mathrm{~cd}$ & $101.50 \mathrm{e}$ & $79.64 \mathrm{f}$ & $4.17 \mathrm{~cd}$ & $6.75 \mathrm{f}$ & $7.59 \mathrm{~g}$ & 37.73 ghi & $39.87 \mathrm{e}$ & $29.73 \mathrm{f}$ \\
\hline & B5 & $84.86 \mathrm{~d}$ & $101.86 \mathrm{e}$ & $81.22 \mathrm{f}$ & $4.29 \mathrm{~cd}$ & $6.77 \mathrm{f}$ & $7.76 \mathrm{fg}$ & $36.33 \mathrm{hi}$ & $38.3 \mathrm{ef}$ & $35.47 \mathrm{de}$ \\
\hline & $\mathrm{B} 10$ & $93.95 \mathrm{~cd}$ & 108.95 de & $82.22 \mathrm{f}$ & $3.88 \mathrm{~d}$ & $6.78 \mathrm{f}$ & $7.77 \mathrm{fg}$ & $39.03 \mathrm{fgh}$ & $36.33 \mathrm{f}$ & 35.9 de \\
\hline & B15 & $96.83 \mathrm{~cd}$ & 118.64 de & $93.29 \mathrm{f}$ & $4.33 \mathrm{~cd}$ & $6.78 \mathrm{f}$ & $8.14 \mathrm{efg}$ & $35.80 \mathrm{i}$ & 40.27 cde & 34.33 ef \\
\hline \multirow[t]{4}{*}{ N75 } & B0 & $116.30 \mathrm{~cd}$ & 129.63 de & $130.31 \mathrm{e}$ & $4.25 \mathrm{~cd}$ & 7.37 ef & $7.87 \mathrm{efg}$ & $39.43 \mathrm{efg}$ & 41.1 cde & 37.67 cde \\
\hline & B5 & $109.15 \mathrm{~cd}$ & $133.82 \mathrm{de}$ & $136.70 \mathrm{e}$ & $4.50 \mathrm{~cd}$ & $7.67 \mathrm{ef}$ & $8.44 \mathrm{efg}$ & 41.37 bcdef & $40.17 \mathrm{de}$ & $40.1 \mathrm{bcd}$ \\
\hline & B10 & $115.58 \mathrm{~cd}$ & $133.91 \mathrm{de}$ & $136.93 \mathrm{e}$ & $4.17 \mathrm{~cd}$ & 7.75 ef & $9.01 \mathrm{def}$ & 41.13 bcdef & $39.83 \mathrm{e}$ & $42.33 \mathrm{abc}$ \\
\hline & B15 & $118.23 \mathrm{c}$ & $138.23 \mathrm{~d}$ & $183.59 \mathrm{~d}$ & $4.56 \mathrm{~cd}$ & $8.25 \mathrm{e}$ & $9.16 \mathrm{de}$ & 40.83 cdef & 41.17 cde & $42.07 \mathrm{abc}$ \\
\hline \multirow[t]{4}{*}{ N225 } & B0 & $198.10 \mathrm{~b}$ & $234.76 \mathrm{c}$ & $235.43 c$ & $4.71 \mathrm{bcd}$ & 8.73 de & $10.02 \mathrm{~cd}$ & 41.80 bcde & $43.53 \mathrm{abc}$ & $40.27 \mathrm{bcd}$ \\
\hline & B5 & $217.13 b$ & $253.80 \mathrm{bc}$ & $266.20 \mathrm{~b}$ & $4.65 \mathrm{bcd}$ & 8.77 cde & $10.81 \mathrm{bc}$ & $42.33 \mathrm{bcd}$ & 41.57 bcde & $40.7 \mathrm{bcd}$ \\
\hline & B10 & $215.47 \mathrm{~b}$ & $256.47 \mathrm{bc}$ & $285.60 \mathrm{ab}$ & $5.44 \mathrm{ab}$ & $9.75 \mathrm{bcd}$ & $10.84 \mathrm{bc}$ & 40.10 defg & $43.53 \mathrm{abc}$ & $42.7 \mathrm{abc}$ \\
\hline & B15 & $212.06 \mathrm{~b}$ & $269.73 \mathrm{~b}$ & $286.84 \mathrm{ab}$ & $4.74 \mathrm{bcd}$ & $9.85 \mathrm{bcd}$ & $11.13 \mathrm{abc}$ & $42.37 \mathrm{bcd}$ & $43.3 \mathrm{abcd}$ & $42.03 \mathrm{abc}$ \\
\hline \multirow[t]{4}{*}{ N450 } & B0 & 270.84 a & $284.50 \mathrm{~b}$ & $294.56 \mathrm{ab}$ & $4.89 \mathrm{bc}$ & $10.14 \mathrm{bcd}$ & $11.9 \mathrm{ab}$ & $42.50 \mathrm{bcd}$ & $45.93 \mathrm{a}$ & $42.93 \mathrm{abc}$ \\
\hline & B5 & $274.76 \mathrm{a}$ & $341.43 \mathrm{a}$ & $298.38 \mathrm{ab}$ & $4.92 \mathrm{bc}$ & $10.17 \mathrm{bc}$ & $12.42 \mathrm{a}$ & $43.07 \mathrm{abc}$ & $44.73 \mathrm{ab}$ & $43.23 \mathrm{ab}$ \\
\hline & B10 & $293.25 \mathrm{a}$ & $362.59 \mathrm{a}$ & $304.94 \mathrm{a}$ & $6.07 \mathrm{a}$ & $10.33 \mathrm{ab}$ & $12.44 \mathrm{a}$ & $45.60 \mathrm{a}$ & $46.1 \mathrm{a}$ & $46.1 \mathrm{a}$ \\
\hline & B15 & $294.05 \mathrm{a}$ & 367.39 a & $315.48 \mathrm{a}$ & $5.46 \mathrm{ab}$ & $11.72 \mathrm{a}$ & $12.49 \mathrm{a}$ & $43.87 \mathrm{ab}$ & $46.43 \mathrm{a}$ & $46.77 \mathrm{a}$ \\
\hline \multicolumn{2}{|l|}{ Nitrogen } & $298.81^{* * *}$ & $329.06^{* * *}$ & $2.93 .45^{* * *}$ & 9.22 * & $17.55^{* *}$ & $22.89 * *$ & $81.51^{* * *}$ & $19.30 * *$ & 8.19 * \\
\hline \multicolumn{2}{|l|}{ Biochar } & $1.03 \mathrm{~ns}$ & $7.85^{* *}$ & $7.82 * *$ & $1.98 \mathrm{~ns}$ & 4.63 * & $5.56^{* *}$ & $0.83 \mathrm{~ns}$ & 3.33 * & 7.89 * \\
\hline \multicolumn{2}{|l|}{ Nitrogen $\times$ biochar } & $0.36 \mathrm{~ns}$ & $2.17 \mathrm{~ns}$ & $0.25 \mathrm{~ns}$ & $2.19 \mathrm{~ns}$ & $0.98 \mathrm{~ns}$ & $0.43 \mathrm{~ns}$ & $1.62 \mathrm{~ns}$ & $1.06 \mathrm{~ns}$ & $0.79 \mathrm{~ns}$ \\
\hline
\end{tabular}

30 DAS: 30 days after sowing. 45 DAS: 45 days after sowing and 60 DAS: 60 days after sowing. Different letters within the columns show a significant difference between treatments at $p=$

0.05 according to LSD test, and asterisks indicate a significant difference at ${ }^{*} p<0.05,{ }^{* *} p<0.01$, and ${ }^{* * *} p<0.001$ level; ns, not-significant. 
Table 3. Effects of integrated application of biochar and nitrogen on the biomass of rapeseed seedlings.

\begin{tabular}{|c|c|c|c|c|c|c|c|c|c|c|}
\hline \multirow{2}{*}{ Nitrogen Levels } & \multirow{2}{*}{ Biochar Application } & \multicolumn{3}{|c|}{ Leaf Dry Weight (g) } & \multicolumn{3}{|c|}{ Stem Dry Weight (g) } & \multicolumn{3}{|c|}{ Root Dry Weight (g) } \\
\hline & & 30 DAS & 45 DAS & 60 DAS & 30 DAS & 45 DAS & 60 DAS & 30 DAS & 45 DAS & 60 DAS \\
\hline \multirow[t]{4}{*}{ No } & B0 & $0.93 \mathrm{gh}$ & $1.42 \mathrm{~h}$ & $0.52 \mathrm{e}$ & $0.17 \mathrm{fg}$ & $0.44 \mathrm{f}$ & $1.74 \mathrm{~g}$ & $0.21 \mathrm{~g}$ & $0.83 \mathrm{~g}$ & $1.27 \mathrm{i}$ \\
\hline & B5 & $0.92 \mathrm{gh}$ & $1.43 \mathrm{~h}$ & $0.54 \mathrm{e}$ & $0.15 \mathrm{~g}$ & $0.45 \mathrm{f}$ & $1.79 \mathrm{~g}$ & $0.24 \mathrm{defg}$ & $0.86 \mathrm{~g}$ & 1.47 hi \\
\hline & $\mathrm{B} 10$ & $0.96 \mathrm{fgh}$ & $1.44 \mathrm{~h}$ & $0.70 \mathrm{e}$ & $0.18 \mathrm{efg}$ & $0.46 \mathrm{f}$ & $1.80 \mathrm{~g}$ & 0.24 defg & $0.87 \mathrm{~g}$ & $1.69 \mathrm{~h}$ \\
\hline & B15 & $0.88 \mathrm{~h}^{\circ}$ & $1.52 \mathrm{~h}$ & $0.77 \mathrm{e}$ & $0.18 \mathrm{efg}$ & $0.52 \mathrm{f}$ & $1.81 \mathrm{~g}$ & 0.26 abcde & $1.10 \mathrm{f}$ & $2.1 \mathrm{~g}$ \\
\hline \multirow[t]{4}{*}{ N75 } & B0 & $1.05 \mathrm{efg}$ & $1.52 \mathrm{~h}$ & $0.77 \mathrm{e}$ & 0.19 cdef & $0.77 \mathrm{e}$ & $2.25 \mathrm{fg}$ & 0.24 defg & $1.28 \mathrm{f}$ & $2.37 \mathrm{fg}$ \\
\hline & B5 & $1.07 \mathrm{ef}$ & $2.41 \mathrm{~g}$ & $0.94 \mathrm{e}$ & 0.20 bcde & $0.87 \mathrm{de}$ & $3.6 \mathrm{f}$ & $0.23 \mathrm{fg}$ & $1.29 \mathrm{f}$ & $2.53 \mathrm{fg}$ \\
\hline & $\mathrm{B} 10$ & $1.04 \mathrm{efg}$ & $2.41 \mathrm{~g}$ & $1.00 \mathrm{e}$ & 0.19 cdef & $0.90 \mathrm{de}$ & $3.71 \mathrm{f}$ & $0.28 \mathrm{abcd}$ & $1.56 \mathrm{e}$ & $2.64 \mathrm{ef}$ \\
\hline & B15 & $1.10 \mathrm{e}$ & $2.82 \mathrm{f}$ & $1.52 \mathrm{~d}$ & 0.20 bcde & $0.99 \mathrm{~cd}$ & $5.31 \mathrm{~d}$ & $0.29 \mathrm{abc}$ & $1.64 \mathrm{e}$ & $2.86 \mathrm{e}$ \\
\hline \multirow[t]{4}{*}{$\mathrm{N} 225$} & B0 & $1.40 \mathrm{~d}$ & $3.54 \mathrm{e}$ & $1.57 \mathrm{~d}$ & 0.20 bcde & $1.03 \mathrm{~cd}$ & $4.50 \mathrm{e}$ & $0.28 \mathrm{abcd}$ & $2.04 \mathrm{~d}$ & $3.08 \mathrm{e}$ \\
\hline & B5 & $1.43 \mathrm{~d}$ & $4.15 \mathrm{~d}$ & $1.84 \mathrm{~d}$ & 0.20 bcde & $1.04 \mathrm{~cd}$ & $4.51 \mathrm{e}$ & $0.29 \mathrm{abc}$ & $2.17 \mathrm{~cd}$ & $3.41 \mathrm{~d}$ \\
\hline & $\mathrm{B} 10$ & $1.48 \mathrm{~d}$ & $4.15 \mathrm{~d}$ & $1.99 \mathrm{~d}$ & $0.21 \mathrm{abcd}$ & $1.19 \mathrm{c}$ & $5.37 \mathrm{~d}$ & $0.28 \mathrm{abcd}$ & $2.29 \mathrm{bc}$ & $3.64 \mathrm{~cd}$ \\
\hline & B15 & $1.48 \mathrm{~d}$ & $5.67 \mathrm{c}$ & $2.46 \mathrm{c}$ & $0.22 \mathrm{abcd}$ & $1.43 \mathrm{~b}$ & $6.09 c$ & $0.30 \mathrm{a}$ & $2.40 \mathrm{~b}$ & $3.97 \mathrm{c}$ \\
\hline \multirow[t]{4}{*}{ N450 } & B0 & $1.90 \mathrm{ab}$ & $6.25 \mathrm{~b}$ & $2.71 b c$ & $0.22 \mathrm{abcd}$ & $1.51 \mathrm{~b}$ & $7.10 \mathrm{~b}$ & $0.29 \mathrm{abc}$ & $2.24 \mathrm{bcd}$ & $3.83 \mathrm{~cd}$ \\
\hline & B5 & $1.93 \mathrm{a}$ & $6.30 \mathrm{~b}$ & $2.98 \mathrm{~b}$ & $0.23 \mathrm{ab}$ & $1.54 \mathrm{~b}$ & $7.17 \mathrm{~b}$ & 0.25 bcde & $2.31 \mathrm{bc}$ & $4.04 \mathrm{c}$ \\
\hline & B10 & $1.81 \mathrm{bc}$ & $6.37 \mathrm{~b}$ & $3.10 \mathrm{~b}$ & $0.24 \mathrm{a}$ & $1.55 \mathrm{~b}$ & $7.18 \mathrm{~b}$ & 0.26 abcde & $2.40 \mathrm{~b}$ & $4.58 \mathrm{~b}$ \\
\hline & B15 & $1.74 \mathrm{c}$ & $8.34 \mathrm{a}$ & $4.35 \mathrm{a}$ & $0.23 \mathrm{ab}$ & $1.82 \mathrm{a}$ & $8.73 \mathrm{a}$ & $0.30 \mathrm{a}$ & $2.64 \mathrm{a}$ & $5.08 \mathrm{a}$ \\
\hline \multicolumn{11}{|c|}{ F values and Significance levels } \\
\hline \multicolumn{2}{|c|}{ Nitrogen } & $248.01^{* * *}$ & $211.34^{* * *}$ & $142.80 * * *$ & $13.88^{* *}$ & $97.66^{* * *}$ & $112.20^{* * *}$ & $20.40^{* *}$ & $206.23^{* * *}$ & $83.53^{* * *}$ \\
\hline \multicolumn{2}{|l|}{ Biochar } & $0.57 \mathrm{~ns}$ & $109.98^{* * *}$ & $23.88^{* * *}$ & $2.17 \mathrm{~ns}$ & $13.02^{* * *}$ & $63.01^{* * *}$ & $4.66^{*}$ & $39.07^{* * *}$ & $66.42^{* * *}$ \\
\hline \multicolumn{2}{|l|}{ Nitrogen $\times$ Biochar } & $2.08 \mathrm{~ns}$ & $18.24^{* *}$ & $2.84 *$ & $0.24 \mathrm{~ns}$ & $1.40 \mathrm{~ns}$ & $10.68^{* *}$ & $1.36 \mathrm{~ns}$ & $1.45 \mathrm{~ns}$ & $2.78 *$ \\
\hline
\end{tabular}

30 DAS: 30 days after sowing; 45 DAS: 45 days after sowing and 60 DAS: 60 days after sowing. Different letters within the columns show a significant difference between treatments at $p=$

0.05 according to LSD test, and asterisks indicate significant difference at ${ }^{*} p<0.05,{ }^{* *} p<0.01$, and ${ }^{* * *} p<0.001$ level; ns, not significant. 


\subsection{Response of Soil Chemical Properties to Biochar and Nitrogen}

The chemical properties of soil showed a significant response towards biochar and nitrogen fertilizer levels. Values of $\mathrm{NH}_{4}{ }^{+} \mathrm{NO}_{3}{ }^{-}$, total nitrogen (TN), available phosphorus (AP), and available potassium (AK) were measured to estimate the role of integrated application of biochar and nitrogen fertilizers in improving soil fertility. Biochar application, in combination with nitrogen fertilizer significantly affected $\mathrm{NH}_{4}{ }^{+}$and $\mathrm{NO}_{3}{ }^{-}$contents in soil and an increasing trend with the increase in biochar and nitrogen amount was observed (Table 4). Soil $\mathrm{NH}_{4}{ }^{+}$increased up to $20 \%$ for $\mathrm{B} 15+\mathrm{N} 450$ treatment compared to $\mathrm{B} 0+\mathrm{N} 450$. Similarly, $\mathrm{NO}_{3}{ }^{-}$also showed the same response towards biochar and nitrogen application, and an increase of $19 \%$ in soil $\mathrm{NO}^{-3}$ the content was recorded for B15+N450 compared to B0+N450 (Table 4). Nitrogen application, along with biochar, improved the TN content and availability of AP, while AK was significant only for biochar application (Table 4). TN was increased by $68 \%$ in response to $\mathrm{B} 15+\mathrm{N} 450$ treatment as compared to the application without biochar. Similarly, the availability of AP was also increased by up to $61 \%$ for B15+N450 treatment compared to the sole application of nitrogen. Available potassium (AK) showed a similar response to increase with increasing biochar rate, and an increase of $29 \%$ was recorded for high biochar treatment (B15+N450). These results indicated that biochar application can compensate the low and high nitrogen amount by adsorbing more nitrogen in high nitrogen supply to reduce harmful effects of high nitrogen or release nitrogen contained in biochar in low nitrogen supply to overcome nitrogen deficiency and also increase the availability of other essential nutrients ( $\mathrm{P}$ and $\mathrm{K}$ ) and as a result increases soil fertility, growth, and development of rapeseed seedlings.

Application of high biochar revealed significant effects in terms of soil organic carbon (SOC), soil organic matter (SOM), soil EC and $\mathrm{pH}$ while the impact of nitrogen application was not significant. High biochar treatments (B15) improved the SOC and SOM by $69 \%$, as compared to treatments without biochar (Table 4). Biochar application caused significant changes in soil $\mathrm{pH}$ and electric conductivity, while nitrogen remained insignificant. However, higher biochar level (B15) along with different nitrogen levels, enhanced soil $\mathrm{pH}$, and EC (Table 4). Biochar improved soil $\mathrm{pH}$ and electric conductivity by an increase of $25 \%$ and $42 \%$ for $\mathrm{B} 15+\mathrm{N} 450$ compared to $\mathrm{B} 0+\mathrm{N} 450$ treatment (Table 4 ). The above findings showed the prominent role of biochar in increasing soil organic carbon, $\mathrm{EC}$, and $\mathrm{pH}$, which can improve soil quality, water availability, and nutrients supply, which can yield better rapeseed growth.

\subsection{Changes in Shoot and Root Nitrogen Content, TNA and NUtE}

Shoot and root nitrogen contents, total nitrogen accumulation (TNA), and nitrogen utilization efficiency (NUtE) of rapeseed seedlings were measured to reveal the role of biochar in retention, adsorption, and utilization of applied nitrogen and soil nutrients. The integration of biochar with nitrogen significantly improved the TNA, NUtE, and nitrogen content in shoot and root at the intervals of 45 DAS and 60 DAS. Nitrogen content of shoot increased with increasing biochar and nitrogen levels, and an increase of $42 \%$ at 45 DAS and $22 \%$ at 60 DAS was recorded in shoot nitrogen content for $\mathrm{B} 15+\mathrm{N} 450$ treatment compared to $\mathrm{B} 0+\mathrm{N} 450$ (Figure 4). Root nitrogen content also showed a positive response towards an increase in biochar and nitrogen integral application. B15+N450, the treatment improved the root nitrogen content by $48 \%$ at 45 DAS and $22 \%$ at 60 DAS compared to B0+N450 treatment (Figure 4). Interaction between biochar and nitrogen was also significant for shoot and root N content, TNA and NUtE at 45 and 60 DAS (Table 5). B15+N450 treatment increased NUtE by 2\% at 45 DAS and $9 \%$ at 60 DAS compared to B0+N450 (Figure 5). Similarly, increase up to 93\% at 45 DAS, and $62 \%$ at 60 DAS was observed for TNA in B15+N450 treatment compared to B0+N450 treatment (Figure 5). Additionally, a significant interaction was also found between biochar and nitrogen at 45 DAS and 60 DAS intervals for the shoot and root nitrogen contents, total nitrogen accumulation (TNA), and nitrogen utilization efficiency (NUtE). These results indicated that biochar could increase the accumulation of nitrogen by roots and shoots to enhance the utilization of applied nitrogen and improve rapeseed performance. 
Table 4. Integrated effect of biochar and nitrogen application on chemical properties of soil.

\begin{tabular}{|c|c|c|c|c|c|c|c|c|c|c|}
\hline Nitrogen Levels & Biochar Levels & Soil pH & Soil EC & $\begin{array}{l}\text { SOC } \\
\left(g_{\text { kg }}^{-1}\right)\end{array}$ & $\begin{array}{l}\text { SOM } \\
\left(g_{k g}^{-1}\right)\end{array}$ & $\begin{array}{l}\text { NH4+ } \\
\left(\mathrm{mg} \mathrm{kg}^{-1}\right)\end{array}$ & $\begin{array}{l}\text { NO3- } \\
\left(\mathrm{mg} \mathrm{kg}^{-1}\right)\end{array}$ & $\begin{array}{l}\text { T N } \\
\left(\mathrm{g} \mathrm{kg}^{-1}\right)\end{array}$ & $\begin{array}{l}\mathrm{A} \mathrm{P} \\
\left(\mathrm{mg} \mathrm{kg}^{-1}\right)\end{array}$ & $\begin{array}{l}\text { AK } \\
\left.(\mathrm{mg} \mathrm{kg})^{-1}\right)\end{array}$ \\
\hline \multirow[t]{4}{*}{ N0 } & B0 & $6.30 \mathrm{~h}$ & $1.30 \mathrm{~d}$ & $7.21 \mathrm{f}$ & $12.43 \mathrm{f}$ & $1.27 \mathrm{~g}$ & $12.08 \mathrm{e}$ & $0.88 \mathrm{e}$ & $16.76 \mathrm{f}$ & $79.70 \mathrm{~g}$ \\
\hline & B5 & $7.24 \mathrm{fg}$ & $1.33 \mathrm{~d}$ & $9.14 \mathrm{de}$ & 15.75 de & $2.26 \mathrm{f}$ & $14.18 \mathrm{e}$ & $0.99 \mathrm{de}$ & $19.31 \mathrm{ef}$ & $84.04 \mathrm{fg}$ \\
\hline & B10 & 7.37 defg & $1.33 \mathrm{~d}$ & $11.30 \mathrm{bc}$ & $19.48 \mathrm{bc}$ & $2.28 \mathrm{f}$ & $16.53 \mathrm{e}$ & $1.03 \mathrm{de}$ & 19.63 ef & 90.10 def \\
\hline & B15 & $7.72 \mathrm{ab}$ & $1.78 \mathrm{a}$ & $13.38 \mathrm{a}$ & $23.07 \mathrm{a}$ & $3.16 \mathrm{ef}$ & $22.82 \mathrm{de}$ & $1.11 \mathrm{de}$ & $21.01 \mathrm{e}$ & 92.64 cde \\
\hline \multirow[t]{4}{*}{ N75 } & B0 & $6.45 \mathrm{~h}$ & $1.35 \mathrm{~d}$ & $7.74 \mathrm{ef}$ & 13.34 ef & $3.36 \mathrm{de}$ & $25.04 \mathrm{de}$ & $1.11 \mathrm{de}$ & $18.65 \mathrm{ef}$ & $87.27 \mathrm{defg}$ \\
\hline & B5 & $7.22 \mathrm{fg}$ & $1.65 \mathrm{ab}$ & $9.99 \mathrm{~cd}$ & $17.23 \mathrm{~cd}$ & $3.56 \mathrm{cde}$ & $25.17 \mathrm{de}$ & $1.18 \mathrm{cde}$ & $20.49 \mathrm{e}$ & $90.05 \mathrm{def}$ \\
\hline & B10 & 7.42 cdef & $1.71 \mathrm{a}$ & $10.92 \mathrm{c}$ & $18.83 \mathrm{c}$ & 4.05 abcde & 28.29 bcde & 1.26 bcde & $21.55 \mathrm{de}$ & 99.34 bc \\
\hline & B15 & $7.64 \mathrm{abc}$ & $1.81 \mathrm{a}$ & $13.47 \mathrm{a}$ & $23.22 \mathrm{a}$ & $4.25 \mathrm{abcd}$ & $32.25 \mathrm{abcd}$ & $1.45 \mathrm{bcd}$ & $24.53 \mathrm{~cd}$ & $109.66 \mathrm{a}$ \\
\hline \multirow[t]{4}{*}{ N225 } & B0 & $6.39 \mathrm{~h}$ & $1.36 \mathrm{~cd}$ & $7.44 \mathrm{f}$ & $12.83 \mathrm{f}$ & $3.37 \mathrm{de}$ & 27.12 cde & $1.10 \mathrm{de}$ & 18.74 ef & 86.82 efg \\
\hline & B5 & $7.26 \mathrm{efg}$ & $1.41 \mathrm{bcd}$ & $10.01 \mathrm{c}$ & $17.26 \mathrm{c}$ & 3.68 bcde & $30.89 \mathrm{abcd}$ & 1.40 bcde & $25.14 b c$ & 92.47 cde \\
\hline & B10 & $7.35 \mathrm{defg}$ & $1.65 \mathrm{ab}$ & $10.74 \mathrm{c}$ & $18.52 \mathrm{c}$ & $4.52 \mathrm{ab}$ & $33.12 \mathrm{abc}$ & $1.53 \mathrm{abcd}$ & $26.15 \mathrm{bc}$ & 94.46 bcde \\
\hline & B15 & 7.50 bcde & $1.74 \mathrm{a}$ & $13.10 \mathrm{a}$ & $22.58 \mathrm{a}$ & $4.55 \mathrm{ab}$ & $34.51 \mathrm{ab}$ & $1.69 \mathrm{abc}$ & $28.05 \mathrm{ab}$ & $109.46 \mathrm{a}$ \\
\hline \multirow[t]{4}{*}{ N450 } & B0 & $6.23 \mathrm{~h}$ & $1.26 \mathrm{~d}$ & $7.61 \mathrm{ef}$ & 13.12 ef & 4.06 abcde & $30.33 \mathrm{abcd}$ & $1.22 \mathrm{cde}$ & 18.91 ef & 90.63 def \\
\hline & B5 & $7.16 \mathrm{~g}$ & $1.60 \mathrm{abc}$ & $9.89 \mathrm{~cd}$ & $17.05 \mathrm{~cd}$ & $4.48 \mathrm{abc}$ & $32.29 \mathrm{abcd}$ & 1.41 bcde & $25.41 \mathrm{bc}$ & $95.15 \mathrm{bcd}$ \\
\hline & B10 & $7.59 \mathrm{abcd}$ & $1.65 \mathrm{ab}$ & $11.03 \mathrm{c}$ & 19.02 c & $4.52 \mathrm{ab}$ & $33.26 \mathrm{abc}$ & $1.78 \mathrm{ab}$ & $27.86 \mathrm{abc}$ & $101.23 \mathrm{~b}$ \\
\hline & B15 & $7.80 \mathrm{a}$ & $1.79 \mathrm{a}$ & $12.91 \mathrm{ab}$ & $22.26 \mathrm{ab}$ & $4.89 \mathrm{a}$ & $36.11 \mathrm{a}$ & $2.06 \mathrm{a}$ & $30.50 \mathrm{a}$ & $109.72 \mathrm{a}$ \\
\hline \multicolumn{11}{|c|}{ F values and Significance levels } \\
\hline \multicolumn{2}{|c|}{ Nitrogen } & $1.64 \mathrm{~ns}$ & $3.2 \mathrm{~ns}$ & $1.20 \mathrm{~ns}$ & $1.20 \mathrm{~ns}$ & $226.81^{* * *}$ & $104.06^{* * *}$ & $25.09 * * *$ & $21.68^{*}$ & $4.39 \mathrm{~ns}$ \\
\hline \multicolumn{2}{|l|}{ Biochar } & $163.95^{* * *}$ & $25.50 * *$ & $218.16^{* * *}$ & $218.16^{* * *}$ & $35.69 * *$ & $37.11 * *$ & $23.87^{* * *}$ & $36.27 * * *$ & $87.45^{* * *}$ \\
\hline \multicolumn{2}{|l|}{ Nitrogen $\times$ Biochar } & $1.46 \mathrm{~ns}$ & $1.63 \mathrm{~ns}$ & $0.93 \mathrm{~ns}$ & $0.93 \mathrm{~ns}$ & $2.24 \mathrm{~ns}$ & $1.37 \mathrm{~ns}$ & $2.26 \mathrm{~ns}$ & $0.06 \mathrm{~ns}$ & $2.17 \mathrm{~ns}$ \\
\hline
\end{tabular}

SOC: soil organic carbon, SOM: soil organic matter, EC: electric conductivity, TN: total nitrogen, AP: available phosphorus, AK: available potassium, NH4+: ammonium nitrogen, NO3-: nitrate nitrogen. Different letters within the columns show a significant difference between treatments at $p=0.05$ according to LSD test, and asterisks indicate a significant difference at ${ }^{*} p<$ $0.05,{ }^{* *} p<0.01$, and ${ }^{* * *} p<0.001$ level; ns, not-significant. 

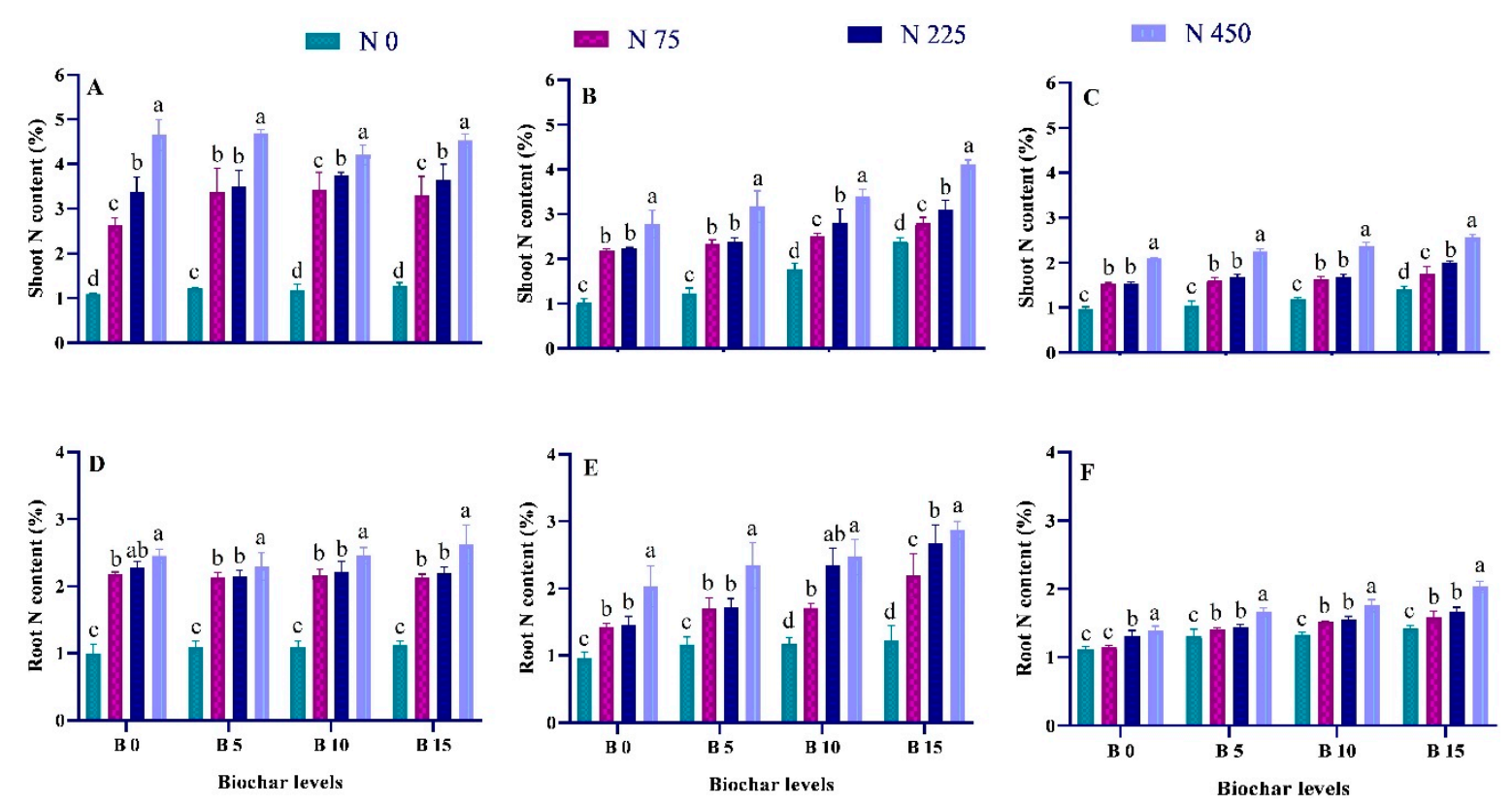

Figure 4. Changes in rapeseed shoot nitrogen content (\%) (A) 30 DAS, (B) 45 DAS and (C) 60 DAS and root nitrogen content (\%) (D) 30 DAS, (E) 45 DAS and (F) 60 DAS under integrated application of biochar and nitrogen. 30 DAS: 30 days after sowing, 45 DAS: 45 days after sowing, 60 DAS: 60 days after sowing, B0: $0 \mathrm{~g}$ biochar $\operatorname{pot}^{-1}$, B5: $10 \mathrm{~g} \mathrm{pot}^{-1}$, B10: $20 \mathrm{~g} \mathrm{pot}^{-1}$ and B15: $30 \mathrm{~g} \mathrm{pot}^{-1}$, N0: $0 \mathrm{mg}$ nitrogen pot $^{-1}$, N75: $133 \mathrm{mg} \mathrm{pot}^{-1}$, N225: $400 \mathrm{mg} \mathrm{pot}^{-1}$ and N450: $800 \mathrm{mg} \mathrm{pot}^{-1}$, error bars represents standard error of three replicates. Differences in letters indicate significant differences according to the LSD test $(p<0.05)$.

Table 5. Significance levels and values of two-way ANOVA are comparing differences in rapeseed physio-chemical parameters.

\begin{tabular}{|c|c|c|c|c|}
\hline Parameters & DAS & Nitrogen & Biochar & Nitrogen $\times$ Biochar \\
\hline \multirow[t]{3}{*}{ Photosynthesis (A) } & 30 & $314.73^{* * *}$ & $0.66 \mathrm{~ns}$ & $0.92 \mathrm{~ns}$ \\
\hline & 45 & $123.44^{* * *}$ & $33.70^{* * *}$ & $0.38 \mathrm{~ns}$ \\
\hline & 60 & $314.25^{* * *}$ & $26.36^{* * *}$ & $0.74 \mathrm{~ns}$ \\
\hline \multirow[t]{3}{*}{ Transpiration (E) } & 30 & $82.23^{* * *}$ & $1.14 \mathrm{~ns}$ & $2.16 \mathrm{~ns}$ \\
\hline & 45 & $118.68^{* * *}$ & $10.52^{* * *}$ & $1.92 \mathrm{~ns}$ \\
\hline & 60 & $110.68^{* * *}$ & $3.78 *$ & 0.33 ns \\
\hline \multirow[t]{3}{*}{ Stomatal conductance (gs) } & 30 & $481.49^{* * *}$ & $2.78 \mathrm{~ns}$ & $0.88 \mathrm{~ns}$ \\
\hline & 45 & $44.54^{* * *}$ & $19.81^{* * *}$ & $1.98 \mathrm{~ns}$ \\
\hline & 60 & $49.85^{* * *}$ & $3.11 *$ & $1.06 \mathrm{~ns}$ \\
\hline \multirow[t]{3}{*}{$\mathrm{CO}_{2} \mathrm{Ci}(\mathrm{ppm})$} & 30 & $33.78^{* * *}$ & $2.04 \mathrm{~ns}$ & $1.16 \mathrm{~ns}$ \\
\hline & 45 & $28.85^{* * *}$ & $16.44 * *$ & $1.06 \mathrm{~ns}$ \\
\hline & 60 & $15.92 * *$ & $5.28^{* *}$ & $0.14 \mathrm{~ns}$ \\
\hline \multirow[t]{3}{*}{ Shoot nitrogen content (\%) } & 30 & $333.96^{* * *}$ & $2.14 \mathrm{~ns}$ & $1.99 \mathrm{~ns}$ \\
\hline & 45 & $127.14^{* * *}$ & $96.70^{* * *}$ & $3.34^{* *}$ \\
\hline & 60 & $299.20 * * *$ & $73.52^{* * *}$ & $2.48^{*}$ \\
\hline \multirow[t]{3}{*}{ Root nitrogen content (\%) } & 30 & $594.46^{* * *}$ & $1.15 \mathrm{~ns}$ & $0.99 \mathrm{~ns}$ \\
\hline & 45 & $80.03^{* * *}$ & $28.59 * * *$ & $2.82 *$ \\
\hline & 60 & $148.49^{* * *}$ & $90.99 * * *$ & $3.07 *$ \\
\hline \multirow[t]{3}{*}{ Total nitrogen accumulation (TNA) } & 30 & $468.81^{* * *}$ & $0.51 \mathrm{~ns}$ & $2.22 \mathrm{~ns}$ \\
\hline & 45 & $189.11^{* * *}$ & $210.31^{* * *}$ & $33.52 * * *$ \\
\hline & 60 & $30.62 * * *$ & $18.67^{* * *}$ & $16.91^{* * *}$ \\
\hline \multirow[t]{3}{*}{ Nitrogen utilization efficiency (NUtE) } & 30 & $131.67^{* * *}$ & $2.52 \mathrm{~ns}$ & $2.18 \mathrm{~ns}$ \\
\hline & 45 & $107.65^{* * *}$ & $4.68^{*}$ & $7.04^{* * *}$ \\
\hline & 60 & $30.62 * * *$ & $18.67^{* * *}$ & $16.91^{* * *}$ \\
\hline
\end{tabular}

DAS; Days after sowing. According to LSD test, asterisks indicate a significant difference at ${ }^{*} p<0.05, * * p<0.01$, and ${ }^{* * *} p<0.001$ level; ns, not-significant. 

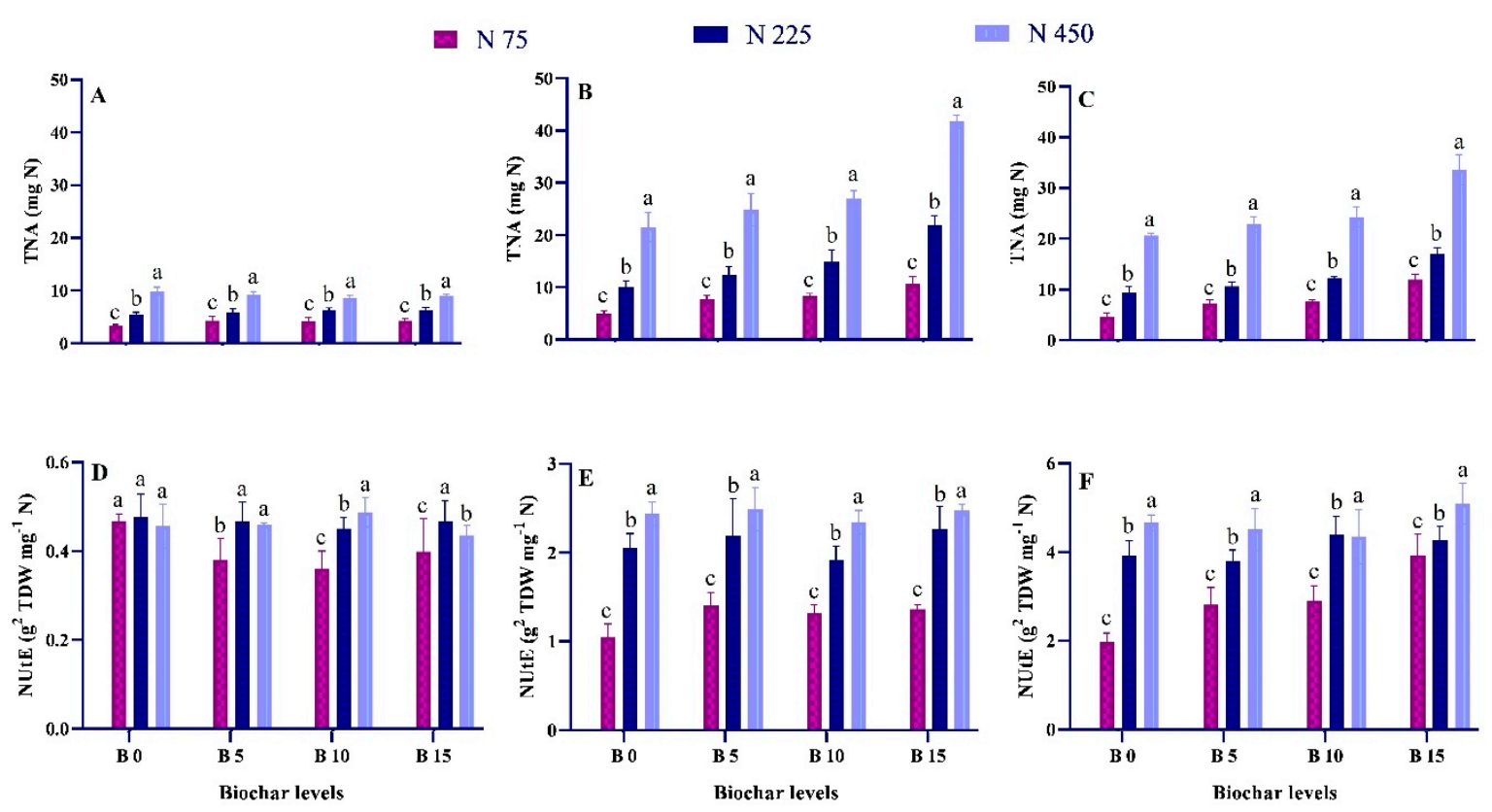

Figure 5. Changes in rapeseed total nitrogen accumulation TNA (mg N) (A) 30 DAS, (B) 45 DAS and (C) 60 DAS and nitrogen utilization efficiency $\left(\mathrm{g}^{2} \mathrm{TDW} \mathrm{mg}^{-1} \mathrm{~N}\right.$ ) (D) 30 DAS, (E) 45 DAS and (F) 60 DAS under integrated application of biochar and nitrogen. 30 DAS: 30 days after sowing, 45 DAS: 45 days after sowing, 60 DAS: 60 days after sowing, B0: $0 \mathrm{~g}$ biochar $\operatorname{pot}^{-1}$, B5: $10 \mathrm{~g} \mathrm{pot}^{-1}$, B10: $20 \mathrm{~g} \mathrm{pot}^{-1}$ and B15: $30 \mathrm{~g} \mathrm{pot}^{-1}$, N0: $0 \mathrm{mg}$ nitrogen pot $^{-1}, \mathrm{~N} 75: 133 \mathrm{mg} \mathrm{pot}^{-1}, \mathrm{~N} 225: 400 \mathrm{mg} \mathrm{pot}^{-1}$ and N450: $800 \mathrm{mg} \mathrm{pot}^{-1}$, error bars represents standard error of three replicates. Differences in letters indicate significant differences according to the LSD test $(p<0.05)$.

\section{Discussion}

Application of rice straw biochar significantly promoted soil chemical properties, nitrogen utilization efficiency, photosynthesis, and rapeseed growth. Only the application of nitrogen fertilizer could result in adverse growth of rapeseed, lower nitrogen utilization efficiency, and soil acidity, which can be compensated through the supplement of organic carbon, nitrogen, phosphorus, potassium, nutrients retention due to porous surface structure, and liming effect of biochar, respectively. The biochar applied to the soil is an organic fertilizer with high carbon content. The rice straw charcoal used in this study contained $47.14 \%$ carbon. Under the condition of sole application of rice straw biochar, the application of 5-30 $\mathrm{g} \mathrm{pot}^{-1}$ straw charcoal increased the organic matter content by $3.32-10.64 \mathrm{~g} \mathrm{~kg}^{-1}$ as compared to soil without straw biochar (Table 4). Soil organic carbon (SOC) improves soil fertility and quality through its prominent effects on the physio-chemical and biological properties of soil. This positive response of SOC in biochar amended pots is because of pronounced adsorption of soluble elements in organic matter and release of labile carbon to soil by rice straw biochar. In addition, biochar has the potential to improve the porosity and moisture content of the soil to facilitate the microorganisms, which can increase the accumulation of organic carbon [25-27].

The amendment of biochar can increase the effective mineral nutrients content of the soil. Biochar itself contains nitrogen, phosphorus, and potassium nutrients, especially the high content of potassium. This study showed that the application of 5-30 $\mathrm{g} \mathrm{pot}^{-1}$ of rice straw charcoal could increase total nitrogen (TN) to $0.15-0.23 \mathrm{~g} \mathrm{~kg}^{-1}$, available phosphorus (AP) to $2.55-4.25 \mathrm{mg} \mathrm{kg}^{-1}$ and available potassium to $4.34-2.94 \mathrm{mg} \mathrm{kg}^{-1}$ as compared to soil with no biochar (Table 4). Simultaneously, the application of 5-30 $\mathrm{g} \mathrm{pot}^{-1}$ rice straw biochar can increase $\mathrm{NH}_{4}{ }^{+}$content in the soil by $0.99-1.89 \mathrm{mg} \mathrm{kg}$ and the $\mathrm{NO}_{3}{ }^{-}$content by $2.10-10.74 \mathrm{mg} \mathrm{kg}^{-1}$ compared with the control without applying biochar and nitrogen (Table 4). The observations of our study indicated that in rice straw biochar due to the presence of organic matter decreased the leaching and increased the immobilization of nitrogen and, thus, increased TN (Table 4). Based on the observed data from this experiment, there was a linear 
relationship between biochar and $\mathrm{NH}_{4}{ }^{+}$and $\mathrm{NO}_{3}{ }^{-}$concentrations, which indicates that rice straw biochar prepared under high temperature enabled the retention of nutrients by providing micro-pores and high surface charge area to increased retention of $\mathrm{NH}^{+4}$ and $\mathrm{NO}^{-3}[28,29]$. Biochar application increases the cation exchange capacities (CEC) and anion exchange [28] capacities (AEC) of soil particles to decrease the nitrogen loss from the soil and increased the nitrogen retention and rates of nitrate $\left(\mathrm{NO}_{3}{ }^{-}-\mathrm{N}\right)$ and ammonium $\left(\mathrm{NH}_{4}{ }^{+}-\mathrm{N}\right)$ nitrogen [30-32]. Both the nutrients provided by biochar and the nutrients retained by the action of biochar increased the nutrient content of nitrogen, phosphorus, and potassium in the soil and are eventually absorbed and utilized by plants.

The application of biochar is beneficial to acidic soil improvement. The rice straw biochar used in our study contained $19.43 \%$ ash content. Soil EC and pH were positively elevated with biochar application while the sole application of nitrogen fertilizers remained insignificant (Table 4). The application of 10-30 $\mathrm{g} \mathrm{pot}^{-1}$ biochar can increase the $\mathrm{pH}$ value of the soil by $0.94-1.42$ and EC by $0.03-0.48$ as compared to soil with zero biochar (Table 4 ) and consequently has an ameliorative effect on the improvement of acidic soil and proper utilization of inorganic fertilizer. Biochar having an alkaline base released high cation concentrations to soil and promotes the consumption reactions of a proton to reduce the acidity of soil and increase soil $\mathrm{pH}$ and EC [33]. This positive response of biochar could be correlated with the presence of higher ash content in biochar [34].

Using biochar can increase the absorption of nitrogen and utilization capacity of crops. Compared with a single application of $800 \mathrm{mg} \mathrm{pot}^{-1}$ nitrogen, when rice straw biochar at $30 \mathrm{~g} \mathrm{pot}^{-1}$ was combined with $800 \mathrm{mg} \mathrm{pot}^{-1}$ nitrogen, a significant increase in leaf area, stem diameter, leaf biomass, stem biomass and root biomass 45 DAS, and 60 DAS was observed respectively, which indicated the combined ameliorative effect of biochar and nitrogen (Tables 2 and 3). The results of the current study revealed that amendment of biochar at $30 \mathrm{~g} \mathrm{pot}^{-1}$ along with nitrogen at $800 \mathrm{mg} \mathrm{pot}^{-1}$ elevated the rates of photosynthesis (A), transpiration (E), stomatal conductance (gs), and intercellular carbon dioxide (Ci) at 45 DAS and 60 DAS respectively, compared to inorganic fertilized pots without biochar (Figures 2 and 3). Biochar porous particles can absorb a large amount of inorganic nitrogen in the soil, thus reducing the damage of high-concentration nitrogen in the early planting stage of plants, and then slowly releasing nitrogen in the middle and late stages of plant growth to meet the necessities of the crop, thus biochar promoting the continuous nitrogen supply status of the soil to promote the physiological processes and growth of rapeseed. At the same time, biochar particles containing oxygen-containing functional groups can increase soil oxidation and water retention $[14,35]$ and also improve the absorption and utilization of fertilizers by crops, thereby effectively promoting the photosynthesis capacity and vegetative growth of the crop. Biochar increased the water holding capacity of the soil and increased the availability of water to roots due to large surface area and porous structure which results in more hydrated plants with more water content to elevate stomatal conductance [36].

The addition of biochar significantly improved the nitrogen utilization efficiency of rapeseed. The integration of $30 \mathrm{~g} \mathrm{pot}^{-1}$ rice straw biochar combined with $800 \mathrm{mg} \mathrm{pot}^{-1}$ nitrogen fertilizer enhanced root nitrogen content, shoot nitrogen content, TNA and NUtE at 45 DAS and 60 DAS respectively, compared with the single application of nitrogen at $800 \mathrm{mg} \mathrm{pot}^{-1}$ without using biochar (Figure 4). These results indicate that rice straw biochar produced under high temperature $\left(600{ }^{\circ} \mathrm{C}\right)$ is more stable in retention and adsorption of nitrogen because biochar contains a single and condense form of aromatic carbon rings, it increases the resistance of biochar to nutrient degradation [37], improves the retention and adsorption of nitrogen, thereby improving the nitrogen content in the roots and stem of rapeseed, the accumulation of total nitrogen and the efficiency of nitrogen utilization. The biochar contains energy substances to acts as a microbial substrate for direct adsorption of nitrogen applied to increase the TNA and NUtE [38]. Similar ameliorative effects of biochar to enhance the nitrogen accumulation and utilization were previously reported [8,29]. In summary, the application of biochar has improved soil quality, nitrogen use efficiency, and plant photosynthesis rates, thus having a significant impact on the economic and sustainable production of rapeseed [39]. 


\section{Conclusions}

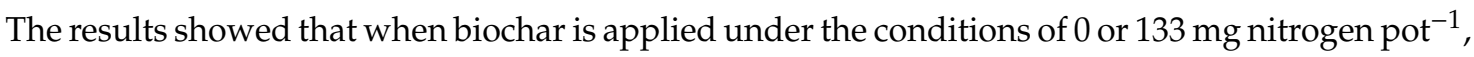
the biomass of rapeseed tends to increase, but the observed difference is not significant. This indicates that the effect of applying biochar under nitrogen deficiency conditions is limited. On the contrary, the simultaneous application of $800 \mathrm{mg} \mathrm{pot}^{-1}$ nitrogen fertilizer and 5-20 $\mathrm{g} \mathrm{pot}^{-1}$ biochar will adversely affect the initial growth of rapeseed seedlings because of the high nitrogen content in the soil. Simultaneously, the results of this current research showed that $30 \mathrm{~g} \mathrm{pot}^{-1}$ straw biochar and $800 \mathrm{mg} \mathrm{pot}^{-1}$ nitrogen fertilizer at 45 DAS and 60 DAS can significantly improve soil fertility, nitrogen utilization efficiency, and promote rapeseed growth. Therefore, further research is needed to study the long-term effects of this comprehensive application of straw bio-carbon and nitrogen for sustainable crop production.

Author Contributions: L.H. and Z.X. envisioned the main idea of the study. Z.K. conducted the experiment and wrote the manuscript. K.Z. helped in experiment. M.N.K. analyzed the data and S.F. revised the manuscript. All authors have read and agreed to the published version of the manuscript.

Funding: This research and the APC was funded by Hubei Agricultural Science and Technology innovation project; (2016 62000000 1045) Huazhong Agricultural University first-class discipline construction project.

Acknowledgments: The authors are thankful to Hubei Agricultural Science and Technology innovation project; Huazhong Agricultural University first-class discipline construction project for funding this research.

Conflicts of Interest: The authors of this manuscript declared no conflict of interest.

\section{References}

1. Challenge, T. Feeding the world in 2050-An Australian's perspective. Food Aust. 2010, 62, 401-402.

2. Arif, M.; Ali, K.; Jan, M.T.; Shah, Z.; Jones, D.L.; Quilliam, R.S. Integration of biochar with animal manure and nitrogen for improving maize yields and soil properties in calcareous semi-arid agroecosystems. Field Crop. Res. 2016, 195, 28-35. [CrossRef]

3. Jones, D.L.; Cross, P.; Withers, P.J.A.; Deluca, T.H.; Robinson, D.A.; Quilliam, R.S.; Harris, I.M.; Chadwick, D.R.; Edwards-Jones, G. REVIEW: Nutrient stripping: The global disparity between food security and soil nutrient stocks. J. Appl. Ecol. 2013, 50, 851-862. [CrossRef]

4. Hu, Q.; Hua, W.; Yin, Y.; Zhang, X.; Liu, L.; Shi, J.; Zhao, Y.; Qin, L.; Chen, C.; Wang, H. Rapeseed research and production in China. Crop J. 2017, 5, 127-135. [CrossRef]

5. Li, X.; Li, Q.; Yang, T.; Nie, Z.; Chen, G.; Hu, L. Responses of plant development, biomass and seed production of direct sown oilseed rape (Brassica napus) to nitrogen application at different stages in Yangtze River Basin. Field Crop. Res. 2016, 194, 12-20. [CrossRef]

6. He, H.; Yang, R.; Li, Y.; Ma, A.; Cao, L.; Wu, X.; Chen, B.; Tian, H.; Gao, Y. Genotypic variation in nitrogen utilization efficiency of oilseed rape (Brassica napus) under contrasting $\mathrm{N}$ supply in pot and field experiments. Front. Plant Sci. 2017, 8, 1825. [CrossRef]

7. Feng, Z; Z Zhu, L. Impact of biochar on soil N2O emissions under different biochar-carbon/fertilizer-nitrogen ratios at a constant moisture condition on a silt loam soil. Sci. Total Environ. 2017, 584, 776-782. [CrossRef] [PubMed]

8. Shen, Q.; Hedley, M.; Camps Arbestain, M.; Kirschbaum, M.U.F. Can biochar increase the bioavailability of phosphorus? J. Soil Sci. Plant Nutr. 2016, 16, 268-286. [CrossRef]

9. Ju, X.; Liu, X.; Zhang, F.; Roelcke, M. Nitrogen fertilization, soil nitrate accumulation, and policy recommendations in several agricultural regions of China. Ambio 2004, 33, 300-305. [CrossRef]

10. Ozer, H. Sowing date and nitrogen rate effects on growth, yield and yield components of two summer rapeseed cultivars. Eur. J. Agron. 2003, 19, 453-463. [CrossRef]

11. Jeffery, S.; Verheijen, F.G.A.; van der Velde, M.; Bastos, A.C. A quantitative review of the effects of biochar application to soils on crop productivity using meta-analysis. Agric. Ecosyst. Environ. 2011, 144, 175-187. [CrossRef]

12. Ur Rahim, H.; Mian, I.A.; Arif, M.; Ahmad, S.; Khan, Z. Soil fertility status as influenced by the carryover effect of biochar and summer legumes. Asian J. Agric. Biol. 2020, 8, 11-16. [CrossRef] 
13. Bayu, D.; Tadesse, M.; Amsalu, N. Effect of biochar on soil properties and lead (Pb) availability in a military camp in South West Ethiopia. Afr. J. Environ. Sci. Technol. 2016, 10, 77-85. [CrossRef]

14. Rondon, M.A.; Lehmann, J.; Ramírez, J.; Hurtado, M. Biological nitrogen fixation by common beans (Phaseolus vulgaris L.) increases with bio-char additions. Biol. Fertil. Soils 2007, 43, 699-708. [CrossRef]

15. Suliman, W.; Harsh, J.B.; Abu-Lail, N.I.; Fortuna, A.M.; Dallmeyer, I.; Garcia-Pérez, M. The role of biochar porosity and surface functionality in augmenting hydrologic properties of a sandy soil. Sci. Total Environ. 2017, 574, 139-147. [CrossRef]

16. Olmo, M.; Villar, R.; Salazar, P.; Alburquerque, J.A. Changes in soil nutrient availability explain biochar's impact on wheat root development. Plant Soil 2016, 399, 333-343. [CrossRef]

17. Joseph, S.D.; Camps-Arbestain, M.; Lin, Y.; Munroe, P.; Chia, C.H.; Hook, J.; Van Zwieten, L.; Kimber, S.; Cowie, A.; Singh, B.P.; et al. An investigation into the reactions of biochar in soil. Aust. J. Soil Res. 2010, 48, 501-515. [CrossRef]

18. Dempster, D.N.; Jones, D.L.; Murphy, D.V. Clay and biochar amendments decreased inorganic but not dissolved organic nitrogen leaching in soil. Soil Res. 2012, 50, 216-221. [CrossRef]

19. Rovira, A. Advanced Course. Riv. di Neuroradiol. 2005, 18, 403-404. [CrossRef]

20. Kovar, J.L.; Pierzynski, G.M. Methods of phosphorus analysis for soils, sediments, residuals, and waters. South. Coop. Ser. Bull. 2009, 408, 110.

21. Cataldo, D.A.; Schrader, L.E.; Youngs, V.L. Analysis by Digestion and Colorimetric Assay of Total Nitrogen in Plant Tissues High in Nitrate. Crop Sci. 1974, 14, 854. [CrossRef]

22. Cataldo, D.A.; Haroon, M.H.; Schrader, L.E.; Youngs, V.L. Rapid colorimetric determination of nitrate in plant tissue by nitration of salicylic acid. Commun. Soil Sci. Plant Anal. 1975, 6, 71-80. [CrossRef]

23. Iqbal, A.; He, L.; Khan, A.; Wei, S.; Akhtar, K.; Ali, I.; Ullah, S.; Munsif, F.; Zhao, Q.; Jiang, L. Organic manure coupled with inorganic fertilizer: An approach for the sustainable production of rice by improving soil properties and nitrogen use efficiency. Agronomy 2019, 9, 651. [CrossRef]

24. Abenavoli, M.R.; Longo, C.; Lupini, A.; Miller, A.J.; Araniti, F.; Mercati, F.; Princi, M.P.; Sunseri, F. Phenotyping two tomato genotypes with different nitrogen use efficiency. Plant Physiol. Biochem. 2016, 107, 21-32. [CrossRef]

25. Lawlor, D.W. Carbon and nitrogen assimilation in relation to yield: Mechanisms are the key to understanding production systems. J. Exp. Bot. 2002, 53, 773-787. [CrossRef]

26. Wardle, D.A.; Nilsson, M.C.; Zackrisson, O. Fire-derived charcoal causes loss of forest humus. Science 2008, 320, 629. [CrossRef]

27. Kameyama, K.; Miyamoto, T.; Shiono, T. Influence of biochar incorporation on TDR-based soil water content measurements. Eur. J. Soil Sci. 2014, 65, 105-112. [CrossRef]

28. Mavi, M.S.; Singh, G.; Singh, B.P.; Sekhon, B.S.; Choudhary, O.P.; Sagi, S.; Berry, R. Interactive effects of rice-residue biochar and $\mathrm{N}$-fertilizer on soil functions and crop biomass in contrasting soils. J. Soil Sci. Plant Nutr. 2018, 18, 41-59. [CrossRef]

29. Güereña, D.; Lehmann, J.; Hanley, K.; Enders, A.; Hyland, C.; Riha, S. Nitrogen dynamics following field application of biochar in a temperate North American maize-based production system. Plant Soil 2013, 365, 239-254. [CrossRef]

30. Vaccari, F.P.; Baronti, S.; Lugato, E.; Genesio, L.; Castaldi, S.; Fornasier, F.; Miglietta, F. Biochar as a strategy to sequester carbon and increase yield in durum wheat. Eur. J. Agron. 2011, 34, 231-238. [CrossRef]

31. Xu, N.; Tan, G.; Wang, H.; Gai, X. Effect of biochar additions to soil on nitrogen leaching, microbial biomass and bacterial community structure. Eur. J. Soil Biol. 2016, 74, 1-8. [CrossRef]

32. Abbruzzini, T.F.; Davies, C.A.; Toledo, F.H.; Cerri, C.E.P. Dynamic biochar effects on nitrogen use efficiency, crop yield and soil nitrous oxide emissions during a tropical wheat-growing season. J. Environ. Manag. 2019, 252, 109638. [CrossRef] [PubMed]

33. Schulz, H.; Dunst, G.; Glaser, B. Positive effects of composted biochar on plant growth and soil fertility. Agron. Sustain. Dev. 2013, 33, 817-827. [CrossRef]

34. Chintala, R.; Mollinedo, J.; Schumacher, T.E.; Malo, D.D.; Julson, J.L. Effect of biochar on chemical properties of acidic soil. Arch. Agron. Soil Sci. 2014, 60, 393-404. [CrossRef]

35. Dela Rosa, J.M.; Paneque, M.; Hilber, I.; Blum, F.; Knicker, H.E.; Bucheli, T.D. Assessment of polycyclic aromatic hydrocarbons in biochar and biochar-amended agricultural soil from Southern Spain. J. Soils Sediments 2016, 16, 557-565. [CrossRef] 
36. Sial, T.A.; Lan, Z.; Wang, L.; Zhao, Y.; Zhang, J.; Kumbhar, F.; Memon, M.; Lashari, M.S.; Shah, A.N. Effects of different biochars on wheat growth parameters, yield and soil fertility status in a silty clay loam soil. Molecules 2019, 24, 1798. [CrossRef] [PubMed]

37. Baronti, S.; Vaccari, F.P.; Miglietta, F.; Calzolari, C.; Lugato, E.; Orlandini, S.; Pini, R.; Zulian, C.; Genesio, L. Impact of biochar application on plant water relations in Vitis vinifera (L.). Eur. J. Agron. 2014, 53, $38-44$. [CrossRef]

38. Lehmann, J. Bio-Energy in the Black. Front. Ecol. Environ. 2007, 5, 381-387. [CrossRef]

39. Ippolito, J.A.; Novak, J.M.; Busscher, W.J.; Ahmedna, M.; Rehrah, D.; Watts, D.W. Switchgrass Biochar Affects Two Aridisols. J. Environ. Qual. 2012, 41, 1123-1130. [CrossRef] [PubMed]

Publisher's Note: MDPI stays neutral with regard to jurisdictional claims in published maps and institutional affiliations.

(C) 2020 by the authors. Licensee MDPI, Basel, Switzerland. This article is an open access article distributed under the terms and conditions of the Creative Commons Attribution (CC BY) license (http://creativecommons.org/licenses/by/4.0/). 